\title{
SYSTEM OF PSYCHOLOGICAL AND DIDACTIC TASKS PLAYERS IN THE EDUCATIONAL PROCESS FACE IN THE PARADIGM “TEACHERS - SCHOOLCHILDREN - PARENTS” AMID THE COVID-19 PANDEMIC
}

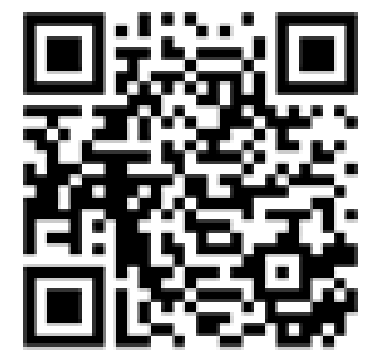

To cite this article:
Oleg Topuzov, Dr. Sc., Prof.

Vice-President,

National Academy of Educational Sciences of Ukraine,

Director,

Institute of Pedagogy,

National Academy of Educational Sciences of Ukraine

Kyiv, Ukraine

proftop@ukr.net

https://orcid.org/0000-0001-7690-1663

Oleksandr Malykhin, Dr. Sc., Prof.

Head, Didactics Department,

Institute of Pedagogy,

National Academy of Educational Sciences of Ukraine

Kyiv, Ukraine

malykhinalex1972@gmail.com

http://orcid.org/0000-0001-6042-6298

Nataliia Aristova, Dr. Sc., Prof.

Head, International Relations and

Research Cooperation Department,

Institute of Pedagogy,

National Academy of Educational Sciences of Ukraine

Kyiv, Ukraine

n.aristova.na@gmail.com

http://orcid.org/0000-0002-0943-8039

Topuzov, O., Malykhin, O. \& Aristova, N. (2021). System of psychological and didactic tasks players in the process face in the paradigm "teachers - schoolchildren - parents" amid the Covid-19 pandemic. Education: Modern Discourses, (4), 23-31.

https://doi.org/10.37472/2617-3107-2021-4-03

Abstract. The paper is aimed at substantiating the system of psychological and didactic tasks all the players in the educational process of general secondary schools (teachers, schoolchildren, parents) face in the paradigm "teachers - schoolchildren - parents" amid the Covid-19 pandemic. The current research is carried out within the framework of the project "Organization of Educational Process in the Content of Unpredicted Changes (the Covid-19 
Pandemic): Comparative Analysis (Ukraine - EU countries)" (Registration No 0121U108690). The solutions of the determined within the research psychological and didactic tasks are targeted at inventing psychodidactic support for parents (possibly grandparents and other relatives) to be successfully used to prevent misunderstandings and even possible conflicts provoked by close communication and coexistence of people who belong to different generations (silent generation, baby boomers, generation $X$, millennials (generation $Y$ ) and generation $Z$ ) within the lockdown and the postpandemic period.

Keywords: Covid-19 pandemic; educational process; system of psychological and didactic tasks; system of postgraduate teacher education.

\section{INTRODUCTION, PROBLEM STATEMENT}

The global challenge for society in general and learning theory in particular has been the close communication and coexistence of people belonging to different generations due to the Covid-19 pandemic (silent generation, baby-boomers, generation $\mathrm{X}$, millennials (generation $\mathrm{Y}$ ) and generation $\mathrm{Z}$ ). And the most acute and even conflict-explosive situations, as it turned out, are caused by the need to organize and implement the educational process at home with the direct or indirect influence of teachers and direct participation (dominance) of representatives of other generations (parents, grandparents and (or) other relatives). Thus, quite unexpectedly, a radically new set of psychological and didactic tasks emerges that need to be solved immediately. Both psychologists and didactics understand that there is a lack of existing effective teaching methods that would be most productive in a completely new environment of coexistence of people in society as a whole and within the educational environment, where communication of its main agents (schoolchildren and teachers) has become indirect, and the supporting role of parents becomes more important. As a result, there is a need to review the existing theoretical and methodological foundations of organizing and providing the educational process at the stage of general secondary education. Under the influence of the Covid-19 pandemic, the problem of understanding the integrated psychological and didactic tasks that all the agents of the educational process face in the paradigm "teachers - schoolchildren - parents" has become more acute. The system of postgraduate teacher education is designed to respond quickly and actively to the changes taking place in the educational system of the country in general and in the system of general secondary education in particular.

The principle ideas that are closely connected with the methodologies for studying pedagogical phenomena and processes and their modeling; theories of personality and theories of personality development; theory of activity and theory of cognitive activity, cognitive independence and cognitive interest; theories of values (basic human values, universal human values, common European values); integration of formal, non-formal and informal education of schoolchildren and teachers; application of information technologies in education; distance education and distance learning; autonomy of the person and personal autonomy; concepts of self-actualization, self-efficacy, self-development, self-education and self-improvement of the individual in educational activities; theories of learning, independent learning and organization of independent learning activities, individualization and differentiation of learning; regularities of professional development of personality in higher pedagogical school; organization and implementation of postgraduate teacher training could be regarded as the basis for deep understanding of the research "Organization of Educational Process in the Content of Unpredicted Changes (the Covid-19 Pandemic): Comparative Analysis (Ukraine EU countries)". The main aim of the paper is to substantiate the system of psychological and didactic tasks players in the process (teachers, schoolchildren, parents) face in the paradigm "teachers - schoolchildren - parents" amid the Covid-19 pandemic. 


\section{LITERATURE REVIEW}

With the rise of information technologies, more and more scholars and practitioners are considering distance education as an effective means that brings about new teaching and learning opportunities for all the players of the educational process (Bozkurt et al., 2015; Bušelić, 2012; Farajollahi et al., 2010; Malykhin, Usca \& Aristova, 2021; Malykhin et al., 2020; Murphy \& Rodríguez-Manzanares, 2012; Sadeghi, 2019; Topuzov et al., 2021). Thus, M. Sadeghi believes that distance learning "might not be the best choice for every student seeking to pursue a college degree or university program but the list of advantages seems to outweigh the list of disadvantages" (Sadeghi, 2019, p. 83). M. Bušelić shares Sadeghi's point of view and explains that distance education that is used for a variety of purposes "offers a myriad of advantages which can be evaluated by technical, social and economic criteria" (Bušelić, 2012, p. 25). The similar idea is expressed by M. Bušelić who emphasizes that distance learning is "an essential part of the mainstream of educational systems in both developed and developing countries" (Bušelić, 2012, p. 25).

\section{METHODOLOGY}

To complete the research tasks the complex of research methods was used, namely: the analysis of scientific research on the problem (to identify the current research on the problem of organizing the educational process in different countries); the method of comparative analysis (to identify the similar educational phenomena and process in the countries of the European Union and in Ukraine under the same conditions (before and during the Covid-19 pandemic)); the method of terminological analysis (to investigate the legal base which regulates the functioning educational systems in the countries of the European Union and in Ukraine); the methods of forecasting and modeling (to identify the potential opportunities of the system of teachers' postgraduate education targeted at rapid overcoming of difficulties which all the key players of the educational process face in the paradigm "teachers - students - parents" amid the Covid-19 pandemic); the method of scientific extrapolation (to implement the constructive ideas of the foreign experience of organizing educational process amid Covid-19 pandemic and to use the positive experience obtained in the system of national education) and the method of netnography (to analyze educational institutions websites in the countries of the European Union and in Ukraine to get information about changes in their functioning amid the Covid-19 pandemic).

\section{MAIN RESULTS}

The current research is carried out within the framework of the project "Organization of Educational Process in the Content of Unpredicted Changes (the Covid-19 Pandemic): Comparative Analysis (Ukraine - EU countries)” (Registration № 0121U108690). The research object is educational process in Ukraine and the countries of the European Union. The research subject is the peculiarities of educational process in Ukraine and the countries of the European Union amid unpredicted influences (the Covid-19 pandemic). The research aim is to generalize and compare foreign experience of organizing educational process during pandemic in order to use it in the national educational system. Project performers determine the tasks in compliance with the research object, subject and aim:

- to carry out a comparative analysis of the experience of organizing educational process in Ukraine and the countries of the European Union in the 21st century basing on the scientific literature on the problem and the legal and regulatory framework for the provision of educational services; 
- to organize and conduct analytical and diagnostic work based on the author's questionnaires and aimed at identifying main trends in organizing the educational process in Ukraine and the countries of the European Union due to unpredicted global impacts which may include the Covid-19 pandemic;

- to study the experience of using updated forms of organization, methods, techniques and teaching aids (based on the integration of traditional and innovative approaches, technologies, methods and techniques) while introducing distance and blended learning in Ukraine and the countries of the European Union on a comparative basis during the Covid-19 pandemic;

- to find out the updated system of integrated psychological and didactic tasks all the key players in the educational process face in the paradigm "teachers - schoolchildren - parents" amid the Covid-19 pandemic;

- to identify the potential of the system of postgraduate teacher education targeted at rapid overcoming the difficulties all the key players in the educational process face in the paradigm "teachers - schoolchildren - parents" amid the Covid-19 pandemic;

- to prepare instructional guidelines and reference books for educators on the possibilities of using positive experience of organizing educational process in the EU during the Covid-19 pandemic in the national educational system of Ukraine.

To substantiate the system of psychological and didactic tasks all the key players in the educational process of general secondary schools (teachers, schoolchildren and parents) face in the paradigm "teachers - schoolchildren - parents" amid the Covid-19 pandemic the project performers developed two web-based questionnaires using Google Forms in the Ukrainian language. The first questionnaire "Educational process amid the Covid-19 pandemic (for school principals, school counselors and school teachers)" was aimed at investigating school principals', school counselors' and school teachers' readiness to respond to the educational challenges during the pandemic.

\section{Questionnaire 1}

(for school principals, school counselors and school teachers)

\section{EDUCATIONAL PROCESS AMID COVID-19 PANDEMIC}

\section{Instructions:}

Dear school principals, school counselors and school teachers,

Thank you for taking part in this study.

The information will help determine school principals', school counselors' and teachers' attitudes towards educational process amid the Covid-19 pandemic.

It should take about 30 minutes to complete this questionnaire.

\section{Position (Please select one response)}

- a novice teacher

- a category-1 teacher

- a category-2 teacher

- a higher category teacher

- a resource teacher

- a school principal

- a school counselor

2. How many years of work experience do you have? (Please select one response)

- up to three years

- from 3 to 10 years

- from 10 to 20 years

- more than 20 years 
3. Gender (Please select one response)

- Male

- Female

4. Have you already had any previous experiences of teaching remotely before the full transition of educational process to distance teaching and learning caused by the Covid-19 pandemic? (Please select one response)

- Yes

- No

5. Do you agree with the following statement: The system of education was fully equipped to implement the policy of distance education amid Covid-19 pandemic. (Please select one response)

- Yes

- No

- It is hard for me to agree or disagree with this statement

6. What is your attitude towards distance teaching and learning caused by Covid-19 pandemic? (Please select one response)

- Positive

- Negative

- It is hard for me to answer this question

7. What educational platforms or open educational resources do you use in your lessons (while teaching remotely)? What, in your opinion, are their advantages?

8. Can you evaluate the level of your knowledge and skills necessary to use information technologies for distance teaching and learning amid Covid-19 pandemic? (Please select one response)

- High

- Sufficient

- Average

- Low

9. Do you agree that existing technical capabilities enable teachers to assess pupils' academic and educational achievements? (Please select one response)

- Yes

- No

- It is hard for me to answer this question

10. What forms of distance teaching and learning do you find most relevant amid the Covid-19 pandemic? (Please select one response)

- Video conferencing lessons

- Online consultations

- E-mail lessons

- E-learning courses

11. Can you determine main problems and difficulties you have already had to face due to the transition of traditional classroom teaching and learning to the distance one?

12. Can you suggest your own hierarchy of educational problems and difficulties caused by the shift to distance teaching and learning (ranging from the most complicated problems or difficulties to the least complicated ones which is hard to overcome at the current stage and in the future)

13. Can you determine the hierarchy of positive changes connected with the transition of traditional classroom teaching and learning to the distance one? 
The second questionnaire "Transformations in relations in families with school-age children connected with shift of tradition-based learning to distance learning caused by the Covid-19 pandemic (for parents)" was targeted at investigating the changes in relations in families with schoolchildren.

\section{Questionnaire 2}

(for parents)

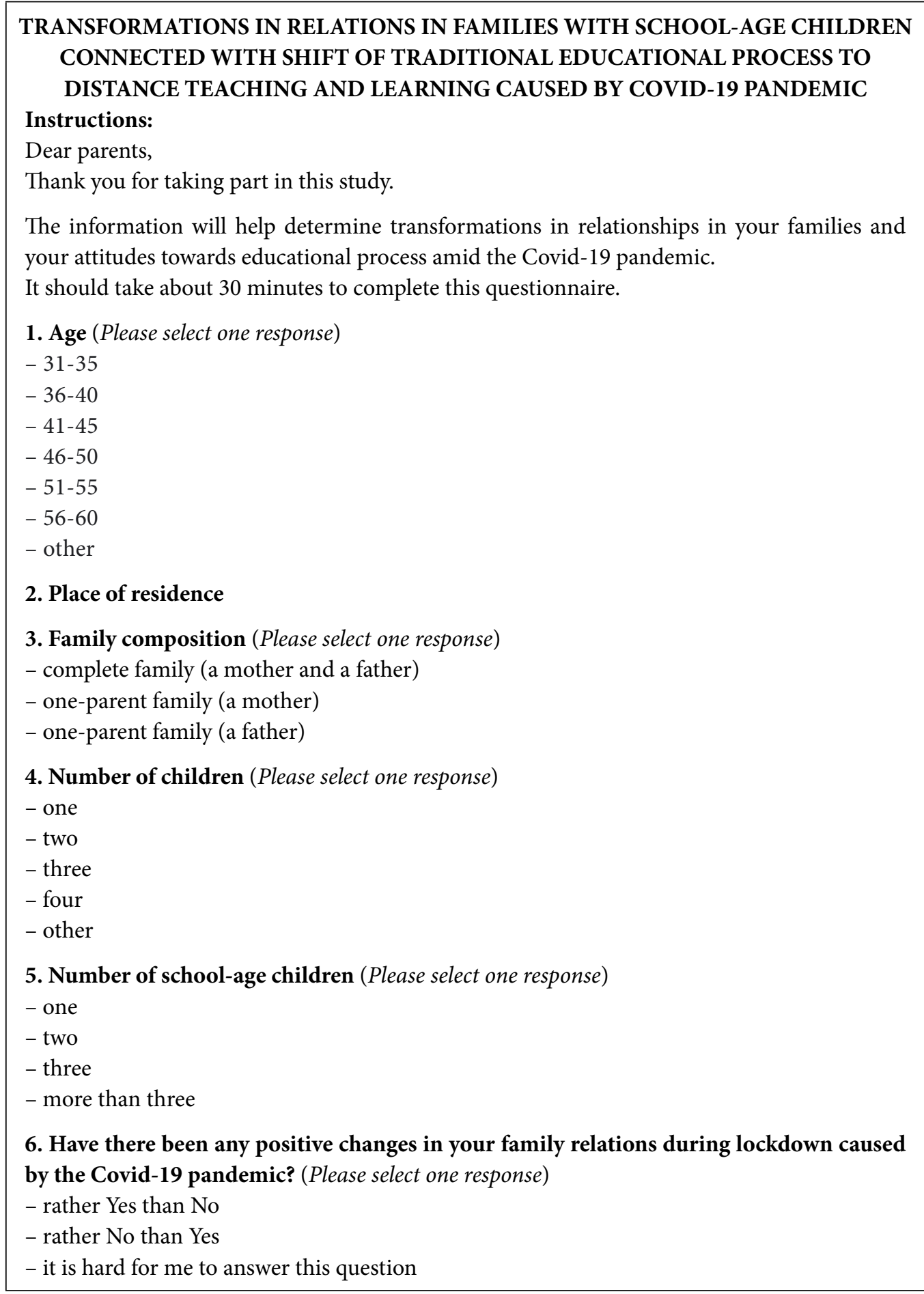


7. Can you list positive changes in your family relations during lockdown caused by the Covid-19 pandemic?

8. Have there been any negative changes in your family relations during lockdown caused by the Covid-19 pandemic? (Please select one response)

- rather Yes than No

- rather No than Yes

- it is hard for me to answer this question

9. Can you list all the problems you have already faced due to the shift of traditional education to distance teaching and learning caused by the Covid-19 pandemic?

10. Did you ask your parents who belong to another generation to assist you with your school-age children during lockdown caused by the Covid-19 pandemic? (Please select one response)

- Yes

- No

11. If you asked your parents to assist you with your school-age children during lockdown caused by the Covid-19 pandemic, please, describe what way they assisted you?

12. If you asked your parents to assist you with your school-age children during lockdown caused by the Covid-19 pandemic, please, describe what, in your opinion, the most valuable efforts were made by your parents?

The new Law of Ukraine "On Complete General Secondary Education" (2020) implies the fundamental reform of the system of general secondary education and declares the upbringing of young citizens of Ukraine as bearers of common European values. And as a result there is a great demand for training New Ukrainian School teachers as agents of change and transmitters of common European values. The Covid-19 pandemic has become a global challenge for the educational system in Ukraine and Ukrainian society as a whole, as an integral part of the world human community, which is forced to respond quickly and effectively to socio-economic transformations due to the need to review almost all spheres of human life in the context of unpredicted global influences.

The system of general secondary education in Ukraine is in a state of active substantive and procedural changes aimed at ensuring sustainable personal development in the context of integration and adaptation of the system of values inherent in Ukrainian society and the citizen of Ukraine to the system of common European values and universal values in the globalized world in the context of realization of the Concept of "New Ukrainian School" (2016). Thus, the identified problem requires a thorough theoretical and methodological understanding, and on this basis, the development of psychological-and-didactic and didactic-and-methodological support of the educational process in general secondary education institutions in modern realities preconditioned by the unpredicted global impacts associated with the Covid-19 pandemic.

And it is the system of postgraduate teacher education that can become an effective means of combining the efforts of scientists and practitioners to ensure the emergence of updated educational content (taking into account the transformation of perception of common European and human values), as well as innovative (due to modern unpredictable global challenges) approaches, technologies, forms of organization, methods, techniques and means of teaching in the system of general secondary education. 
This problem is especially sharpened in the context of unpredicted challenges caused by the Covid-19 pandemic that the Ukrainian system of education in general and the system of general secondary education in particular face nowadays. And the system of teachers' postgraduate education can be turned into an effective mechanism able to react quickly and on changes that are taking place in the system of general secondary education in the context of cardinal revisions of content, forms, methods and techniques of education in the innovative realities caused by the impacts of real and predicted consequences of the Covid-19 pandemic. That is resulted in the appearance of the need for New Ukrainian teachers as agents of change and transmitters of basic and universal human values as well as common European values.

The information obtained as a result of generalization and analysis of the empiric data gives the project performers all the verified foundations to identify the substantiated system of psychological and didactic tasks:

1) providing and maintaining the psychological and didactic comfort of communication in the paradigm "teachers - schoolchildren - parents", associated with the shift to distance learning;

2) transformations connected with the motivation of learning and associated with the transition of traditional (classroom) learning to distance and / or blended formats;

3) organization of study time and workplace of schoolchildren as the central agents of the educational process;

4) taking into account the individual psychological and individual typological peculiarities of schoolchildren in determining the most effective forms of organization, methods and tools of teaching and learning;

5) stimulation of positive reflection of all participants of the educational process;

6) updating the system of assessment and control of learning outcomes (assessment, selfassessment, control and self-control);

7) health-protection task in the paradigm "teachers - schoolchildren - parents" (protection of physical and psychological health of all participants of the educational process).

\section{CONCLUSIONS}

Thus, the system of postgraduate teacher training is to be changed. So, we offer to upgrade the content of the postgraduate teacher training aimed at overcoming negative impact of the Covid-19 pandemic on the system of general secondary education in the context of deep realization of transformations that are being held in the system of human values. Simultaneously with equipping secondary school teachers with effective psychodidactic instruments to be used in the classroom that is absolutely different under conditions of the Covid-19 pandemic influences the solutions of the determined psychological and didactic tasks are targeted at inventing psychodidactic support for parents (possibly grandparents and other relatives) to be successfully used to prevent misunderstandings and even possible conflicts provoked by close communication and coexistence of people who belong to different generations (silent generation, baby boomers, generation X, millennials (generation $\mathrm{Y}$ ) and generation $\mathrm{Z}$ ) within the lockdown and the postpandemic period. 


\section{REFERENCES}

Bozkurt, A., Akgun-Ozbek, E., Yilmazel, S., Erdogdu, E., Ucar, H., Guler, E., Sezgin, S., Karadeniz, A., Sen-Ersoy, N., Goksel-Canbek, N., Dincer, G., Ari, S., \& Aydin, C. H. (2015). Trends in Distance Education Research: A Content Analysis of Journals 2009-2013. The International Review of Research in Open and Distributed Learning, 16(1), 330-363. https://doi. org/10.19173/irrodl.v16il.1953

Bušelić, M. (2012). Distance Learning - Concepts and Contributions. Oeconomica Jadertina, 1, 23-34.

Farajollahi, M., Zare, H., Hormozi, M., Sarmadi, M. R., \& Zarifsanaee, N. (2010). A Conceptual Model for Effective Distance Learning in Higher Education. Turkish Online Journal of Distance Education, 11(3), 63-77.

Malykhin, O., Usca, S., \& Aristova, N. (2021). University lecturers' views on distance education during the Covid-19 pandemic: Ukrainian-Latvian comparative studies. Society. Integration. Education. Proceedings of the International Scientific Conference, 5, 145-157. https://lib.iitta. gov.ua/725471/

Murphy, E. \& Rodríguez-Manzanares, M. (2012). Rapport in Distance Education. International Review of Research in Open and Distributed Learning, 13(1), 167-190. https://doi. org/10.19173/irrodl.v13i1.1057

Sadeghi, M. (2019). A Shift from Classroom to Distance Learning: Advantages and Limitations. International Journal of Research in English Education, 4(1), 80-88. https://doi.org/10.29252/ ijree.4.1.80

Topuzov, O., Malykhin, O., Usca, S., \& Aristova, N. (2021). Ukrainian-Latvian comparative studies on university education: common European values and current challenges. In V. Lubkina, G. Strods, O. Vindaca (Eds.), Society. Integration. Education: Volume I. Higher Education. (pp. 696-706). Rezekne Academy of Technologies. https://doi.org/10.17770/ sie2021vol1.6423 